\title{
Characterization of DNA Synthesis in Salt-Treated HeLa Cell Nuclei
}

\author{
Sei-ichi Tanuma, Takemi Enomoto and Masa-atsu Yamada \\ Department of Physiological Chemistry, Faculty of Pharmaceutical Sciences, \\ University of Tokyo, Hongo, Bunkyo-ku, Tokyo 113, Japan
}

\begin{abstract}
The effects of salt treatment of isolated nuclei on the nature of DNA synthesis and on the solubilization of DNA polymerase $a$ have been investigated. Treatment with $0.2 \mathrm{M} \mathrm{KCl}$ resulted in a deficiency in the function to join Okazaki fragments, whereas the synthesis of these fragments was little affected. No DNA synthesis was observed in $0.3 \mathrm{M} \mathrm{KCl}$-treated nuclei. DNA synthesis in $0.2 \mathrm{M} \mathrm{KCl}$-treated nuclei required ATP, $\mathrm{Mg}^{2+}$ and four deoxyribonucleoside triphosphates, and was markedly inhibited by arabinofuranosylcytosine triphosphate and aphidicolin, but not by $2^{\prime}, 3^{\prime}$-dideoxythymidine triphosphate. This suggests that the DNA synthesis is the replicative-type, catalyzed by DNA polymerase $\alpha$. DNA polymerase $\alpha$ in $0.3 \mathrm{M} \mathrm{KCl-nuclear}$ extract was detected as two active forms distinct in their binding affinities for DNA. In $0.2 \mathrm{M} \mathrm{KCl-treated} \mathrm{nuclei,} \mathrm{only} \mathrm{one} \mathrm{active} \mathrm{form} \mathrm{with} \mathrm{high} \mathrm{binding}$ affinity was retained, indicating that this form is responsible for the synthesis of Okazaki fragments.
\end{abstract}

The mechanism of DNA replication in mammalian cells is complex, and its details have yet to be clarified. The identification and characterization of replication factors in connection with the processes of DNA replication are an important step toward determining the molecular mechanism of DNA replication.

Isolated nuclei from mammalian cells have proved a useful experimental system for the study of DNA replication in vitro (1-10). Although by using such an in vitro system, DNA replication of mammalian cells has been shown to proceed in a discontinuous manner through the formation of short fragments (Okazaki fragments) which are subsequently converted into high molecular weight DNA, the nuclear system is too complex to study the factors involved in the processes of DNA replication.

Seki and Mueller (11) have demonstrated the dissociation and reconstitution of the nuclear system by mild salt treatment. Such a reconstituted subnuclear system using salt-treated nuclei as a "natural template" may be valuable for identifying and characterizing the factors involved in DNA replication. Recently, by using a reconstituted subnuclear system, Brun and Weissbach (12) found evidence that suggests that RNA polymerase I is involved in the priming event for DNA synthesis.

In the course of our study on the effect of salts on DNA synthesis in isolated nuclei, we observed that in the presence of $0.2 \mathrm{M} \mathrm{KCl}$, isolated nuclei can synthesize Okazaki fragments, but are deficient in the function to join them. Thus, it seemed possible that by treatment of isolated nuclei with salts at appropriate concentrations, factors 
necessary for some step of DNA replication could be selectively solubilized from nuclei, leaving salt-treated nuclei capable of other steps of DNA replication.

We have analyzed here the nature of DNA synthesis in HeLa cell nuclei after treatment with varying concentrations of $\mathrm{KCl}$. In addition, we have characterized the nuclear salt-extract in regard to DNA polymerase $a$, a candidate for a replication enzyme (13-20). We provide evidence that isolated nuclei contain two active forms of DNA polymerase $\alpha$ distinct in their binding affinities for DNA, and that one active form retained in $0.2 \mathrm{M} \mathrm{KCl}$-treated nuclei is responsible for the synthesis of Okazaki fragments.

\section{MATERIALS AND METHODS}

Isolation and salt treatment of nuclei. Nuclei were isolated from HeLa S3 cells $3 \mathrm{~h}$ after release from the hydroxyurea block as described previously $(21,22)$. Salt treatment of isolated nuclei was performed according to the method of Seki and Mueller (11). Isolated nuclei were suspended in 9 volumes of buffer A (10 mM Tris- $\mathrm{HCl}(\mathrm{pH} 7.8), 3 \mathrm{mM} \mathrm{MgCl}$, $1 \mathrm{mM} \mathrm{Na}{ }_{2}$ EDTA, $2 \mathrm{mM}$ 2-mercaptoethanol and $0.1 \mathrm{mM}$ phenylmethylsulfonylfluoride) containing various concentrations of $\mathrm{KCl}$. After being kept at $0^{\circ} \mathrm{C}$ for $20 \mathrm{~min}$, the suspension was centrifuged at $800 \times \mathrm{g}$ for $5 \mathrm{~min}$. The precipitate was washed once with buffer $\mathrm{A}$ then centrifuged as before to pellet the salt-treated nuclei.

Assay for DNA synthesis. The activity of DNA synthesis in isolated and salt-treated nuclei was assayed in a standard reaction mixture containing $100 \mathrm{mM} \mathrm{KCl}, 40 \mathrm{mM}$ Tris- $\mathrm{HCl}$ (pH 7.8), $5 \mathrm{mM} \mathrm{MgCl} 2,1 \mathrm{mM} \mathrm{Na}{ }_{2}$ EDTA, $2 \mathrm{mM}$ 2-mercaptoethanol, $4 \mathrm{mM}$ ATP, $100 \mu \mathrm{M}$ each dATP, dGTP, dCTP, and $20 \mu \mathrm{M}\left[{ }^{3} \mathrm{H}\right] \mathrm{dTTP}(0.67 \mathrm{Ci} / \mathrm{mmol})$. The concentration of nuclei was set at $1 \times 10^{6} /$ tube (total volume of $150 \mu \mathrm{l}$ ). The radioactivity incorporated into $5 \%$ trichloroacetic acid precipitable material was collected on a Whatman GF/C glass fiber filter and counted with a liquid scintillation spectrometer $(21,22)$.

Alkaline sucrose gradient. DNA was pulse-labelled by incubating $1 \times 10^{6}$ nuclei at $37^{\circ} \mathrm{C}$ in the standard reaction mixture, except that the concentration of $\left[{ }^{3} \mathrm{H}\right] \mathrm{dTTP}$ was $10 \mu \mathrm{M}$ (3.4 Ci/mmol). Nuclei were lysed by an addition of alkaline lysis solution containing $0.3 \mathrm{M}$ $\mathrm{KOH}, 0.7 \mathrm{M} \mathrm{KCl}, 10 \mathrm{mM} \mathrm{Na}{ }_{2}$ EDTA and $2 \%$ sarkosyl. The lysate was kept at $4{ }^{\circ} \mathrm{C}$ for at least $2 \mathrm{~h}$ before applying it to an alkaline sucrose gradient. The alkaline sucrose gradient was $5-20 \%$ sucrose in a solution containing $0.3 \mathrm{M} \mathrm{KOH}, 0.7 \mathrm{M} \mathrm{KCl}, 1 \mathrm{mM} \mathrm{Na} 2$ DETA and $0.1 \%$ sarkosyl $(8,9)$. Centrifugation was performed at 22,500 r.p.m. for $14 \mathrm{~h}$ at $4^{\circ} \mathrm{C}$ in a Hitachi RPS-25 rotor.

Assay for DNA polymerase activity. DNA polymerase $\alpha, \beta$ and $\gamma$ were assayed essentially according to the method described by Spadari et al. (15).

$\alpha$ assay: The $150 \mu \mathrm{l}$ assay mixture contained $50 \mathrm{mM} \mathrm{KCl}, 40 \mathrm{mM}$ Tris- $\mathrm{HCl}(\mathrm{pH} \mathrm{7.8),}$ $5 \mathrm{mM} \mathrm{MgCl}_{2}, 1 \mathrm{mM} \mathrm{Na} \mathrm{EDTA}_{2} 2 \mathrm{mM}$ 2-mercaptoethanol, $100 \mu \mathrm{M}$ each dATP, dGTP and dCTP, $20 \mu \mathrm{M}\left[{ }^{3} \mathrm{H}\right] \mathrm{dTTP}(0.67 \mathrm{Ci} / \mathrm{mmol})$ and $45 \mu \mathrm{g}$ activated DNA. Samples were incubated at $37^{\circ} \mathrm{C}$ for $30 \mathrm{~min}$. The reaction was stopped by chilling the mixture to $0^{\circ} \mathrm{C}$ and by the addition of carrier DNA to a final concentration of $200 \mu \mathrm{g} / \mathrm{ml}$ and trichloroacetic acid at $5 \%$. The DNA precipitate was collected and its radioactivity was measured as described above.

$\beta$ assay: The assay was essentially the same as that for polymerase $\alpha$, except that $10 \mathrm{mM}$ $N$-ethylmaleimide was present.

$\gamma$ assay: The $150 \mu \mathrm{l}$ assay mixture contained $100 \mathrm{mM} \mathrm{KCl}, 40 \mathrm{mM}$ Tris- $\mathrm{HCl}(\mathrm{pH} \mathrm{7.8)}$, $0.5 \mathrm{mM} \mathrm{MnCl}, 2 \mathrm{mM}$ 2-mercaptoethanol, $40 \mu \mathrm{M}\left[{ }^{3} \mathrm{H}\right] \mathrm{dTTP}(0.33 \mathrm{Ci} / \mathrm{mmol})$ and $5 \mu \mathrm{g}$ 
poly $(\mathrm{rA}) \cdot$ oligo $(\mathrm{dT})_{12}$. Incubation was carried out at $37^{\circ} \mathrm{C}$ for $30 \mathrm{~min}$. The amount of incorporated $\left[{ }^{3} \mathrm{H}\right] \mathrm{dTMP}$ into the homopolymer was measured as described under the polymerase $\alpha$ assay.

Single stranded-DNA cellulose column chromatography. Single stranded-DNA cellulose was prepared essentially according to the method of Alberts and Herrick (23) with slight modification. The DNA-cellulose mixture was dried at room temperature by evacuation in a dessicator containing $\mathrm{P}_{2} \mathrm{O}_{5}$ instead of by lyophylization. This procedure yielded DNAcellulose with a higher concentration of ligand than with the original method. The nuclear salt-extract was centrifuged at $105,000 \times \mathrm{g}$ for $1 \mathrm{~h}$ then dialyzed against buffer B $(20 \mathrm{mM}$ Tris- $\mathrm{HCl}$ (pH 8.1), $1 \mathrm{mM} \mathrm{Na}{ }_{2}$ EDTA, $2 \mathrm{mM}$ 2-mercaptoethanol and $10 \%$ glycerol) containing $50 \mathrm{~mm} \mathrm{KCl}$. All operations were carried out at $0-4^{\circ} \mathrm{C}$. The sample was applied to a column previously equilibrated with $50 \mathrm{mM} \mathrm{KCl}$-buffer $\mathrm{B}$, and was washed with the same buffer then eluted stepwise with buffer B containing $0.18,0.27$ and $0.55 \mathrm{M} \mathrm{KCl}$.

\section{RESULTS AND DISCUSSION}

Effect of $\mathrm{KCl}$ on DNA synthesis in isolated nuclei. We first examined the effect of salt on DNA synthesis in isolated nuclei. DNA synthesis was critically dependent on the concentration of $\mathrm{KCl}$ in the reaction mixture (Fig. 1). This result agrees with the observation of Hershey et al. (6). Maximal activity was observed at $0.1 \mathrm{M} \mathrm{KCl}$. The overall activity of DNA synthesis in isolated nuclei at 0.04 and $0.2 \mathrm{M} \mathrm{KCl}$ was reduced by about one half that at the optimum.

Products synthesized at the three different ionic strengths, 0.04, 0.1 and $0.2 \mathrm{M}$ $\mathrm{KCl}$, were analyzed by sedimentation in alkaline sucrose gradients. As shown in Fig. 2 , about $50 \%$ of the product synthesized at $0.1 \mathrm{M} \mathrm{KCl}$ after a 10 -min incubation was distributed in short fragments, the rest was in high molecular weight DNA fractions toward the bottom. At $0.04 \mathrm{M} \mathrm{KCl}$, both the syntheses of short fragments and high molecular weight DNA decreased to about $50 \%$ of the values at $0.1 \mathrm{M} \mathrm{KCl}$. The product synthesized at $0.2 \mathrm{M} \mathrm{KCl}$ was predominantly in short fragments with a slight decrease in the amount as compared to $0.1 \mathrm{M} \mathrm{KCl}$. At this concentration, little radioactivity was detected in the high molecular weight DNA fractions after additional incubation. The deficiency in the function to synthesize high molecular weight DNA in isolated nuclei in the presence of $0.2 \mathrm{M} \mathrm{KCl}$ may be due to the dissociation of the factors necessary for joining the short fragments. This possibility is confirmed in the next section.

The decrease in DNA synthesis at $0.04 \mathrm{M} \mathrm{KCl}$ may be due to the reduction of DNA chain growth rate within the short fragments (Okazaki fragments). Nuclei pre-treated with $0.2 \mathrm{M} \mathrm{KCl}(0.2 \mathrm{M} \mathrm{KCl}$-treated nuclei), which synthesize Okazaki fragments only, as described in the following section (Fig. 4), are suitable to examine this possibility. The pattern of the dependency curve of $\mathrm{KCl}$ in the $0.2 \mathrm{M} \mathrm{KCl}$-treated nuclei was similar to that of isolated nuclei (Fig. 1). $0.1 \mathrm{M} \mathrm{KCl}$ gave maximal activity. The product analysis by sedimentation in an alkaline sucrose gradient revealed that both the amount and size of the Okazaki fragments synthesized at $0.04 \mathrm{M} \mathrm{KCl}$ were smaller than those synthesized at $0.1 \mathrm{M} \mathrm{KCl}$ (Fig. 3). At the three different ionic strengths with the omission of ATP, the DNA synthesizing activities were less than $10 \%$ of the optimum, and the products were found in fragments smaller than the Okazaki fragments.

These results suggest that the ionic environment has a critical effect on the opera- 

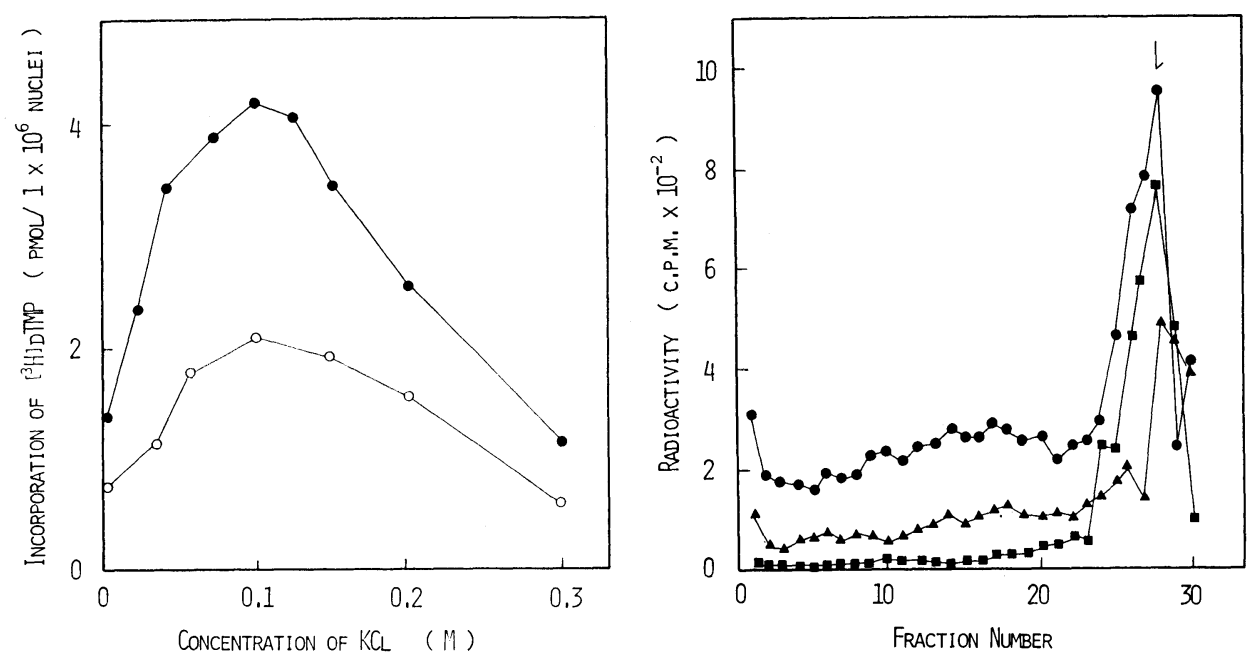

Fig. 1. Effect of $\mathrm{KCl}$ on DNA synthesis in isolated and $0.2 \mathrm{M} \mathrm{KCl}$-treated nuclei. Activities of DNA synthesis in isolated (- $\longrightarrow$ ) and in $0.2 \mathrm{M} \mathrm{KCl}$-treated $(-\circ)$ nuclei were assayed in the standard reaction mixture except for the concentration of $\mathrm{KCl}$. Incubation was carried out for $10 \mathrm{~min}$ at $37^{\circ} \mathrm{C}$. The incorporation of $\left[{ }^{3} \mathrm{H}\right] \mathrm{dTMP}$ into acid insoluble material was measured as described under Materials AND Methods.

Fig. 2. Sedimentation of newly synthesized DNA in isolated nuclei in an alkaline sucrose gradient at different concentrations of $\mathrm{KCl}$. Isolated nuclei were incubated for $10 \mathrm{~min}$ at $37^{\circ} \mathrm{C}$ in the standard reaction mixture except for the concentration of $\mathrm{KCl} ; 0.04(-\mathbf{-}-), 0.1(-\longrightarrow)$ and $0.2(-\square-) \mathrm{M}$. The products were lysed by adding alkaline lysis solution, then they were centrifuged in alkaline sucrose gradients as described under MATERIALS AND Methods. The arrow indicates the location of ${ }^{14} \mathrm{C}$-labelled DNA of the nucleosome monomer from HeLa S3 cells (4-5S). The top of the gradient is at the right, the direction of sedimentation is to the left.

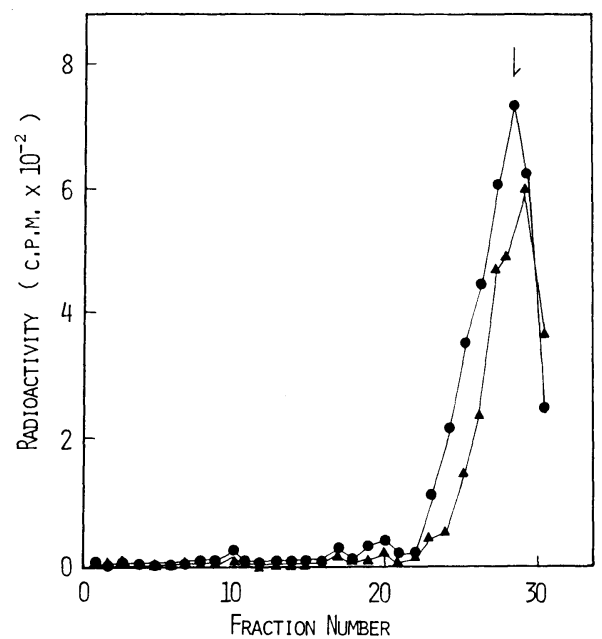

Fig. 3. Analysis of the size distribution of the DNA synthesized in $0.2 \mathrm{M} \mathrm{KCl}$-treated nuclei at different concentration of $\mathrm{KCl} .0 .2 \mathrm{M} \mathrm{KCl}$-treated nuclei were incubated for $10 \mathrm{~min}$ at $37^{\circ} \mathrm{C}$ in the standard reaction mixture except for the concentration of $\mathrm{KCl} ; 0.04(-\mathbf{\Delta}-)$ and $0.1(-\bullet-) \mathrm{M}$. The same marker as in Fig. 2 was used. The top of the gradient is the right, the direction of sedimentation is to the left. 
tion of the DNA replication apparatus in isolated nuclei by affecting the interactions of the replication factors with DNA and/or each other.

DNA synthesis in salt-treated nuclei. Treatment of isolated nuclei with appropriate concentration of salt, may make it possible to solubilize selectively the replication factors required for some step of DNA replication, leaving the nuclei capable of carrying out another step of DNA replication. To test this possibility, we treated isolated nuclei with $\mathrm{KCl}$ at concentrations higher than $0.1 \mathrm{M}$ and analyzed the products synthesized in salt-treated nuclei.

The nuclear structure of salt-treated nuclei was maintained intact even after $\mathrm{KCl}$ treatment at a concentration as high as $0.3 \mathrm{M}$. The optimal conditions and requirements for DNA synthesis in salt-treated nuclear systems were similar to those in the isolated nuclear system. As shown in Fig. 4A, the product synthesized in isolated nuclei, after a 10-min incubation, was distributed in short fragments and in high molecular weight DNA fractions as described above. In the $0.15 \mathrm{M} \mathrm{KCl-treated}$

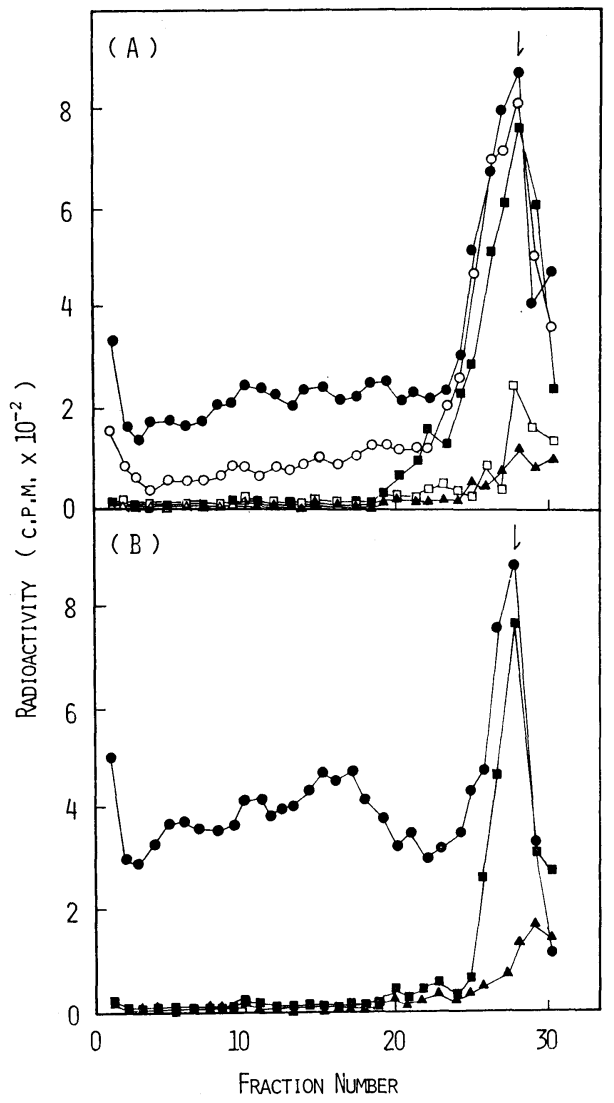

Fig. 4. Sedimentation in an alkaline sucrose gradient of newly synthesized DNA in isolated and $0.2 \mathrm{M} \mathrm{KCl}$-treated nuclei. (A): isolated (-๑), and $0.15(-\bigcirc-), 0.2(-\square-), 0.25(-\square-)$ and 0.3 (一 - - M KCl-treated nuclei were incubated for $10 \mathrm{~min}$ at $37^{\circ} \mathrm{C}$. (B): isolated (- -$), 0.2$ (一-) and 0.3 (- - - ) M KCl-treated nuclei were incubated for $30 \mathrm{~min}$ at $37^{\circ} \mathrm{C}$. The same marker as in Fig. 2 was used. The top of the gradient is at the right, the direction of sedimentation is to the left. 
nuclei, short fragments accumulated, and high molecular weight DNA was synthesized with low efficiency. In the $0.2 \mathrm{M} \mathrm{KCl}$-treated nuclei, short fragments were synthesized with slightly lower efficiency than in isolated nuclei; no significant amount of radioactivity was found in addition to that found in them. Low and little capacity to synthesize short fragments were observed in the 0.25 and $0.3 \mathrm{M} \mathrm{KCl}$-treated nuclei, respectively. Although a marked increase in the synthesis of high molecular weight DNA was observed in isolated nuclei after a 30 -min incubation as compared to 10 min, little radioactivity was found in the high molecular weight DNA fractions in the $0.2 \mathrm{M}$ and $0.3 \mathrm{M} \mathrm{KCl}$-treated nuclei even after the same duration of pulse length (Fig. 4B).

The short fragments observed in $0.2 \mathrm{M} \mathrm{KCl-treated} \mathrm{nuclei} \mathrm{may} \mathrm{correspond} \mathrm{to}$ Okazaki fragment-like DNA intermediates that should be joined into high molecular weight DNA, not to the artificial fragments produced by the action of endonucleases and/or uracil-DNA- $N$-glycosidase. This hypothesis is supported by the following observations. First, when $0.2 \mathrm{M} \mathrm{KCl-treated} \mathrm{nuclei} \mathrm{were} \mathrm{prepared} \mathrm{from} \mathrm{cells} \mathrm{previous-}$ ly labelled with $\left[{ }^{14} \mathrm{C}\right]$ thymidine, and when the size of the DNA was analyzed by sedimentation in an alkaline sucrose gradient, the size distribution was virtually identical with that of isolated nuclei (Fig. 5). Second, the joining function was re-
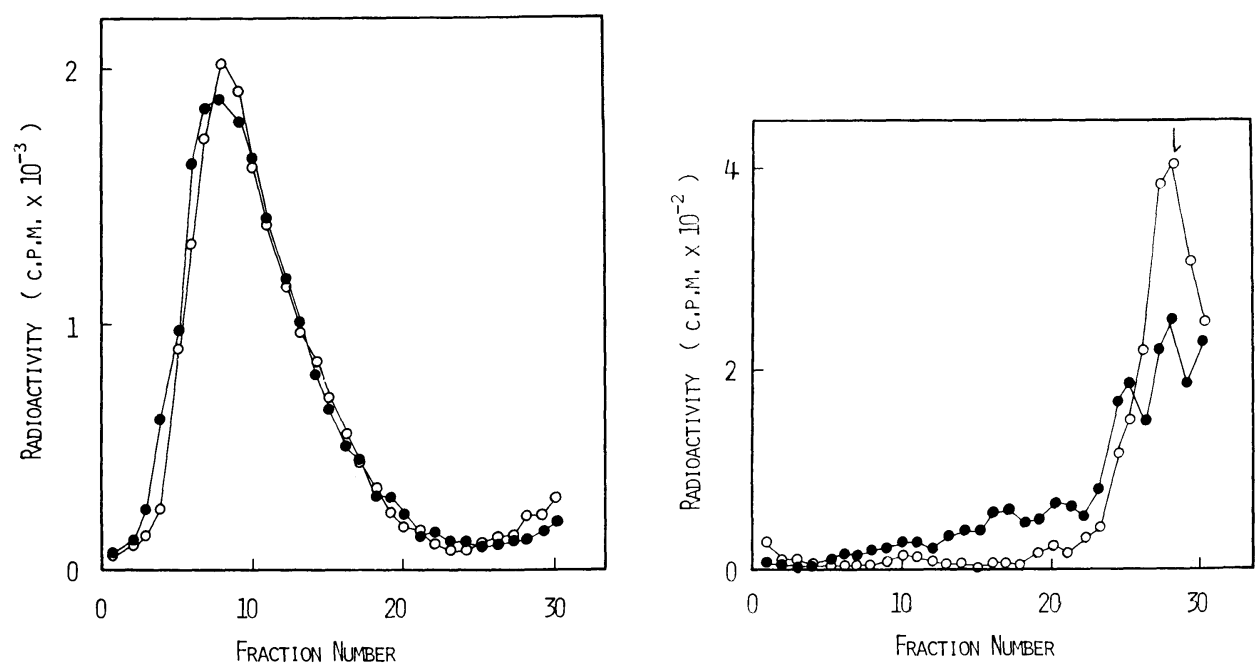

Fig. 5. Analysis of the size distribution of DNA in isolated and $0.2 \mathrm{M} \mathrm{KCl-treated} \mathrm{nuclei.}$ Isolated and $0.2 \mathrm{M} \mathrm{KCl}$-treated nuclei were prepared from cells previously labelled with $\left[{ }^{14} \mathrm{C}\right]-$ thymidine then incubated for $10 \mathrm{~min}$ at $37^{\circ} \mathrm{C}$ in the standard reaction mixture except that $\left[{ }^{3} \mathrm{H}\right] \mathrm{dTTP}$ was replaced by unlabelled dTTP. The samples first were lysed by the alkaline lysis solution then layered on alkaline sucrose gradients as described under MATERIALS AND METHODs. Sedimentation was carried out at 22,500 r.p.m. for $4 \mathrm{~h}$ at $4^{\circ} \mathrm{C}$ in a Hitachi RPS-25 rotor; isolated ( $\left.-\longrightarrow\right)$ and $0.2 \mathrm{M} \mathrm{KCl}$-treated nuclei (-○-).

Fig. 6. Alkaline sucrose gradients demonstrating the effect of the complementary nuclear saltextract on the size of DNA synthesized in $0.2 \mathrm{M} \mathrm{KCl}$-treated nuclei. After $0.2 \mathrm{M} \mathrm{KCl}$-treated nuclei had been pulse-labelled for $2 \mathrm{~min}$ at $37^{\circ} \mathrm{C}, 130$-fold unlabelled dTTP and 3 nuclear equivalents of complementary salt-extract were added to the reaction mixture. The samples then were incubated for an additional $10 \mathrm{~min}$ after which they were prepared for alkaline sucrose sedimentation as described under MATERIALS AND Methods; $0.2 \mathrm{M} \mathrm{KCl-treated} \mathrm{nuclei} \mathrm{(-○一)} \mathrm{and} \mathrm{reconstituted}$ nuclei (-O). 
stored to $0.2 \mathrm{M} \mathrm{KCl-treated} \mathrm{nuclei} \mathrm{by} \mathrm{again} \mathrm{adding} \mathrm{the} \mathrm{complementary} \mathrm{nuclear} \mathrm{salt-}$ extract (Fig. 6).

These results indicate that the short fragments synthesized in $0.2 \mathrm{M} \mathrm{KCl}$-treated nuclei are Okazaki fragments, and that $0.2 \mathrm{M} \mathrm{KCl-treated} \mathrm{nuclei} \mathrm{retain} \mathrm{the} \mathrm{replication}$ factors and structure needed for the synthesis of Okazaki fragments, but that they are deficient in some essential factors for the joining of these fragments. The $0.2 \mathrm{M} \mathrm{KCl}-$ treatment of isolated nuclei, therefore, make it possible to dissect the replication factors connected with two steps of DNA replication; the synthesis and joining of Okazaki fragments.

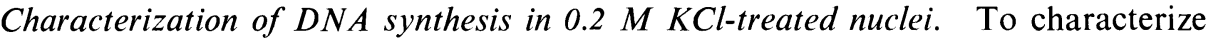
DNA synthesis in $0.2 \mathrm{M} \mathrm{KCl}$-treated nuclei, the requirements and the effect of DNA polymerase-inhibitors were investigated (Table 1). All four deoxyribonucleoside triphosphates were required for maximal activity. A marked reduction in activity was observed when even one deoxyribonucleoside triphosphate was omitted. The optimal concentration of ATP was around $4 \mathrm{mM}$. With the omission of ATP, the activity was less than $10 \%$ of the optimum. At an ATP concentration of $4 \mathrm{mM}$, the optimal $\mathrm{Mg}^{2+}$ concentration was $5 \mathrm{mM}$. With the omission of $\mathrm{Mg}^{2+}$, activity was $5 \%$ of the optimum.

Arabinofuranosylcytosine triphosphate (araCTP) inhibits DNA polymerase $a$ more strongly than $\beta(24,25)$. As shown in Table 1 , a 5 - or 10 -fold molar excess of araCTP over dCTP caused more than $90 \%$ inhibition. $2^{\prime}, 3^{\prime}$-dideoxythymidine triphosphate $\left(\mathrm{d}_{2} \mathrm{TTP}\right)$, a potent inhibitor of DNA polymerase $\gamma$ and $\beta(19,25)$, essentially had no effect at a $\mathrm{d}_{2}$ TTP/dTTP concentration ratio of 1.5 or 3 . Aphidicolin, a specific inhibitor of DNA polymerase $\alpha(26,27)$, completely inhibited DNA synthesis at a concentration of 1 or $3 \mu \mathrm{g} / \mathrm{ml}$. These observations were corraborated by the identification of DNA polymerase in $0.2 \mathrm{M} \mathrm{KCl}$-treated nuclei as described in the following section.

Our results strongly suggest that DNA synthesis in $0.2 \mathrm{M} \mathrm{KCl-treated} \mathrm{nuclei} \mathrm{is} \mathrm{of}$ the replicative type, catalyzed by DNA polymerase $a$.

TABLE 1. REQUIREMENTS FOR AND THE EFFECT OF INHIBITORS ON DNA SYNTHESIS IN 0.2 M KCl-TREATED NUCLEI

\begin{tabular}{|c|c|}
\hline Reaction mixture & $\%$ of control \\
\hline Complete & 100 \\
\hline \multicolumn{2}{|l|}{ Deletions } \\
\hline - dATP & 23 \\
\hline -dGTP & 22 \\
\hline$-\mathrm{dCTP}$ & 22 \\
\hline -dATP, dGTP, dCTP & 4 \\
\hline$-\mathrm{Mg}^{2+}$ & 5 \\
\hline -ATP & 8 \\
\hline \multicolumn{2}{|l|}{ Additions } \\
\hline $\operatorname{araCTP} \quad 0.5(\mathrm{mM})$ & 7 \\
\hline $1.0(\mathrm{mM})$ & 4 \\
\hline $30(\mathrm{mM})$ & 87 \\
\hline $60(\mathrm{mM})$ & 79 \\
\hline \multirow{2}{*}{$\begin{array}{ll}\text { Aphidicolin } & 1(\mu \mathrm{g} / \mathrm{ml}) \\
& 3(\mu \mathrm{g} / \mathrm{ml})\end{array}$} & 4 \\
\hline & 1 \\
\hline
\end{tabular}

The assays for DNA synthesis in $0.2 \mathrm{M} \mathrm{KCl-treated} \mathrm{nuclei} \mathrm{were} \mathrm{performed} \mathrm{as} \mathrm{described} \mathrm{under}$ MAterials AND Methods with the deletions and additions listed above. 


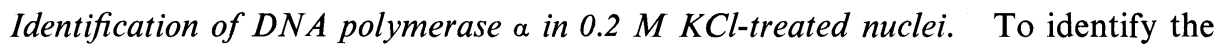
DNA polymerase responsible for the synthesis of Okazaki fragments, we analyzed two nuclear salt-extracts by chromatography of single stranded-DNA cellulose. One is the complementary nuclear extracts of $0.3 \mathrm{M} \mathrm{KCl}$-treated nuclei $(0.3 \mathrm{M} \mathrm{KCl}$ nuclear extract, NE-0.3) which is incapable of DNA synthesis by itself. Another is the extract from $0.2 \mathrm{M} \mathrm{KCl}$-treated nuclei with $0.3 \mathrm{M} \mathrm{KCl}(0.2-0.3 \mathrm{M} \mathrm{KCl}$ nuclear extract, NE-0.2-0.3), which contains some essential factors for the synthesis of Okazaki fragments. Almost all the DNA polymerase activities in both nuclear extracts were inhibited by $10 \mathrm{mM} N$-ethylmaleimide. Low but appreciable amounts of DNA polymerase activity to utilize poly(rA) $\cdot$ oligo $(\mathrm{dT})_{12}$ as a template-primer were detected in both nuclear extracts. More than $95 \%$ of the nuclear DNA polymerase activity, sensitive to $10 \mathrm{mM} N$-ethylmaleimide, was extracted to NE-0.3.

Each nuclear extract was dialyzed against $0.05 \mathrm{M} \mathrm{KCl-buffer} \mathrm{B} \mathrm{then} \mathrm{applied} \mathrm{to} \mathrm{a}$ single stranded-DNA cellulose column previously equilibrated with the same buffer. The column was washed with the same buffer then eluted stepwisely with buffer B containing $0.18,0.27$ and $0.55 \mathrm{M} \mathrm{KCl}$. As shown in Fig. 7A, in the case of NE-0.3,

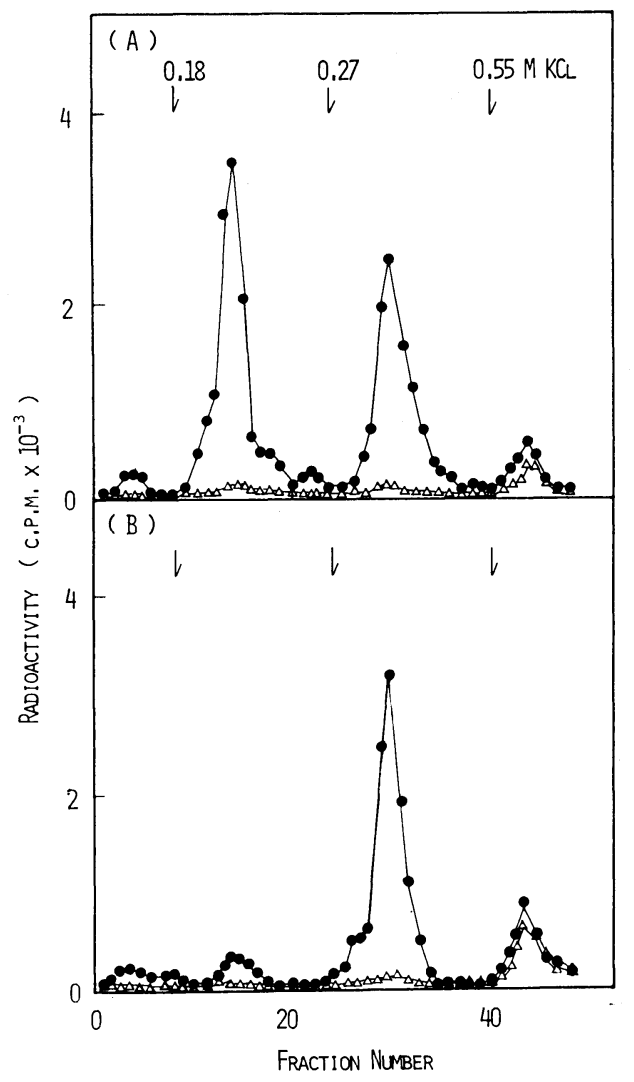

Fig. 7. Single stranded-DNA cellulose column chromatography. (A) 0.3 and (B) $0.2-0.3 \mathrm{M} \mathrm{KCl}$ nuclear extracts were prepared as described under MATERIALS AND Methods. Each nuclear extract was applied to a single stranded-DNA cellulose column previously equilibrated with buffer B-0.05 $\mathrm{M} \mathrm{KCl}$, then washed the same buffer and eluted stepwise with buffer B-0.18, 0.27 and $0.55 \mathrm{M} \mathrm{KCl}$. Fractions were assayed for DNA polymerase $a(-\bullet)$ and $\beta(-\triangle-)$. 
two peaks of DNA polymerase $a$ activity were detected. This heterogeneous chromatographic behavior of DNA polymerase $a$ was reproducible. Bieri-Bonniot and Schuerch (28) have reported a similar result with poly(dT)-CL-Sepharose. Whereas with NE-0.2-0.3, one activity was eluted after changing the $\mathrm{KCl}$ concentration to $0.27 \mathrm{M}$ (Fig. 7B). Low but appreciable amounts of DNA polymerase $\beta$ activity, insensitive to $10 \mathrm{mM} N$-ethylmaleimide, were detected in $0.55 \mathrm{M} \mathrm{KCl}$-eluted fractions. In both cases, the activities eluted at a $\mathrm{KCl}$ concentration lower than $0.55 \mathrm{M}$ were inhibited by more than $95 \%$ by $N$-ethylmaleimide. The further purified, two active forms of DNA polymerase $a$ differed in chromatographyic behavior; in their salt requirements for optimal activity and in their $\mathrm{Km}$ values for dTTP, although the two forms both exhibited properties characteristic of DNA polymerase $a$, sensitivity to $\mathrm{N}$-ethylmaleimide and similar molecular size in velocity sedimentation (not shown).

These observations indicate that isolated nuclei contain two active forms of DNA polymerase $a$ distinct in their binding affinities for DNA or chromatin, and that one active form with the higher binding affinity (retained in $0.2 \mathrm{M} \mathrm{KCl}$-treated nuclei) is responsible for the synthesis of Okazaki fragments. These results are also supported by our observation (38) that the activity of the one form with higher binding affinity changed with a very close temporal relationship to in vivo DNA synthesis.

The widely reported heterogeneity of DNA polymerase $a$ (29-36) may be correlated with its biological functions in the processes of DNA replication. More recently, Wist and Prydz (37) have demonstrated that DNA polymerase $\alpha$ is responsible for gapfilling as well as for elongation in discontinuous DNA synthesis in isolated nuclei. There is also the possibility that another form of DNA polymerase $a$ with a lower binding affinity, may be involved in the filling process in the gaps between adjacent Okazaki fragments.

Acknowledgments. We thank Dr. M. Ohashi and Dr. S. Ikegami for the supply of aphidicolin. This work was supported in part by a Grant-in-Aid from the Ministry of Education, Science and Culture, Japan.

\section{REFERENCES}

1. Friedman, D.L. and G.C. Mueller. A nuclear system for DNA replication from synchronized HeLa cells. Biochim. Biophys. Acta 161, 455-468, 1968

2. Kidwell, W.R. and G.C. Mueller. The synthesis and assembly of DNA subunits in isolated HeLa cell nuclei. Biochem. Biophys. Res. Commun. 36, 756-763, 1969

3. Lynch, W.E., R.F. Brown, T. Umeda, S.G. Langreth and I. Lieberman. Synthesis of deoxyribonucleic acid by isolated liver nuclei. J. Biol. Chem. 245, 3911-3916, 1970

4. TENG, C., D.P. BLoch and R. Roychoudhury. DNA synthesis in nuclei isolated from Ehrlich ascites tumor cells. Biochim. Biophys. Acta 224, 232-245, 1970

5. LyNCh, W.E., T. UMEDA, M. Uyede and I. Lieberman. Nature of the deoxyribonucleic acid made by isolated liver nuclei. Biochim. Biophys. Acta 287, 28-37, 1972

6. Hershey, H.V., J.F. Stieber and G.C. Mueller. DNA synthesis in isolated HeLa nuclei: A system for continuation of replication in vivo. Eur. J. Biochem. 34, 383-394, 1973

7. Hershey, H.V., J.F. STIEBER and G.C. Mueller. Effect of inhibiting the cellular synthesis of RNA, DNA and protein on DNA replicative activity of isolated S-phase nuclei. Biochim. Biophys. Acta 312, 509-517, 1973

8. TSENG, B.T. and M.J. Goulian. DNA synthesis in human lymphocytes: Intermediates in DNA synthesis, in vitro and in vivo. J. Mol. Biol. 99, 317-337, 1975

9. Krokan, H., E. BJRklid and H. Prydz. DNA synthesis in isolated HeLa cell nuclei. Optimalization of the synthesis and characterization of the product. Biochemistry 14, 4227-4232, 
1975

10. Krokan, H., L. Cooke and H. Prydz. DNA synthesis in isolated HeLa cell nuclei. Evidence for in vitro initiation of synthesis of small pieces of DNA and their subsequent ligation. Biochemistry 14, 4233-4237, 1975

11. SeKi, S. and G.C. Mueller. Dissociation and reconstitution of the DNA replicase system of HeLa cell nuclei. Biochim. Biophys. Acta 435, 236-250, 1976

12. Brun, G. and A. Weissbach. Initiation of HeLa cell DNA synthesis in a subnuclear system. Proc. Natl. Acad. Sci. U.S.A. 75, 5931-5935, 1978

13. Weissbach, A., D. Baltimore, F.J. Bollum, R. Callo and D. Korn. Nomenclature of eukaryotic DNA polymerases. Science 190, 401-402, 1975

14. Weissbach, A. Vertebrate DNA polymerases. Cell 5, 101-108, 1975

15. Spadari, S. and A. Weissbach. The interrelation between DNA synthesis and various DNA polymerase activities in synchronized HeLa cells. J. Mol. Biol. 86, 11-20, 1974

16. Chang, L.M.S. and F.J. Bollum. Variation of deoxyribonucleic acid polymerase activities during rat liver regeneration. J. Biol. Chem. 247, 7948-7950, 1972

17. Baril, E.F., O.E. Brown ,M.D. Jenkins, J. LAszlo and H.P. Morris. DNA polymerases I and II in regenerating rat liver and Morris hepatoma. Cancer Res. 33, 1178-1193, 1973

18. Spadari, S. and A. Weissbach. RNA-primed DNA synthesis: Specific catalysis by HeLa cell DNA polymerase a. Proc. Natl. Acad. Sci. U.S.A. 72, 503-507, 1975

19. Edenberg, H.J., S. Anderson and M.L. DePAmphiLis. Involvement of DNA polymerase $a$ in simian 40 DNA replication. J. Biol. Chem. 253, 3273-3280, 1978

20. Hubscher, U., C. Kuenzle and S. Spadari. Functional role of DNA polymerases $\beta$ and $\gamma$. Proc. Natl. Acad. Sci. U.S.A. 76, 2316-2320, 1979

21. Tanuma, S., T. Enomoto and M. Yamada. Changes in the level of poly ADP-ribosylation during a cell cycle. Exp. Cell Res. 117, 421-430, 1978

22. Tanuma, S., T. Enomoto and M. Yamada. Effect of thymidine on poly ADP-ribosylation in vivo. J. Biol. Chem. 254, 4960-4962, 1979

23. Alberts, B. and G. Herrick. DNA-cellulose chromatography. Methods in Enzymol. 21, 198217,1971

24. Yoshida, A., M. Yamada and S. MASaki. Inhibition of DNA polymerase $a$ and $\beta$ of calf thymus by $1-\beta$-D-arabinofuranosylcytosine 5 -triphosphate. Biochim. Biophys. Acta 477, 144 150, 1977

25. WIST, E. The role of DNA polymerase $a, \beta$ and $\gamma$ in nuclear DNA synthesis. Biochim. Biophys. Acta 562, 62-69, 1979

26. Ohashi, M., T. TAguchi and S. IKegami. Aphidicolin: A specific inhibitor of DNA polymerases in the cytosol of rat liver. Biochem. Biophys. Res. Commun. 82, 1084-1090, 1978

27. Ikegami, S., T. Taguchi, M. Ohashi, M. Oguro, H. Nagano and Y. Mano. Aphidicolin prevents mitotic cell division by interfering with activity of DNA polymerase $a$. Nature 275 , 458-460, 1978

28. Bieri-Bonniot, F. and A.R. Schuerch. Molecular heterogeneity of DNA polymerase $a$ from P815 mouse mastocytoma cells. FEBS. Lett. 96, 192-196, 1978

29. Holmes, A.M., I.P. Hesselewood and I.R. Johnston. The occurrence of multiple activities in the high-molecular-weight DNA polymerase fraction of mammalian tissues: A preliminary study of some of their properties. Eur. J. Biochem. 43, 487-499, 1974

30. Matsukage, A., E.W. Bohn and S.H. Wilson. Multiple forms of DNA polymerase in mouse myeloma. Proc. Natl. Acad. Sci. U.S.A. 71, 578-582, 1974

31. Matsukage, A., M. Sivarajan and S.H. Wilson. Studies on DNA a-polymerase of mouse myeloma: Partial purification and comparison of three molecular forms of the enzyme. Biochemistry 15, 5305-5314, 1976

32. Yoshida, S., T. Kondo and T. ANDO. Multiple molecular species of cytoplasmic DNA polymerase from calf thymus. Biochim. Biophys. Acta 353, 463-474, 1974

33. Craig, K.K. and H.M. KeIR. Deoxyribonucleic acid polymerases of BHK-21/c13 cells: Heterogeneity molecular asymmetry and subcellular distribution of the enzymes. Biochem. J. 145, 225-232, 1975 
34. Hachimann, H.J. and A.G. Lezius. High-molecular-weight DNA polymerases from mouse myeloma: Purification and properties of three enzymes. Eur. J. Biochem. 50, 357-366, 1975

35. Nishioka, N., A. Matsukage and T. TAKAhashi. On the binding of DNA polymerase alpha to nuclear structure in mouse myeloma MOPC104E. Cell Strct. and Func. 2, 61-70, 1977

36. Ono, Y., T. Enomoto and M. YamadA. Separation of two forms of HeLa DNA polymerase $a$ with different binding affinity to DNA. Gann 69, 207-212, 1978

37. WIST, E. and H. Prydz. The effect of aphidicolin on DNA synthesis in isolated HeLa cell nuclei. Nucleic Acids Res. 6, 1583-1590, 1979

38. Ono, Y., T. Enomoto and M. Yamada. Variation of two forms of DNA polymerase $a$ during a HeLa cell cycle. Gann 70, 527-532, 1979

(Received for publication, December 10, 1979) 